\title{
Approach for the Classification of Polliniferous Vegetation Using Multispectral Imaging and Neural Networks
}

Jesus Silva; Noel Varela; Jorge L. Díaz-Martinez; Javier Jiménez-Cabas; Omar Bonerge Pineda Lezama

\begin{abstract}
Beekeeping has suffered a serious deterioration in the regions of the world. The possibility of nectar-polliniferous resources has decreased and, therefore, the feeding of bees, with the consequent decrease in production. There is, therefore, a need to improve marketing and diversification systems and to update production techniques and the management of the production process by beekeepers to obtain the quality of honey required by the market [1]. This work proposes the use of spectral information to identify the different pollen-producing plants using remote vision, image processing, and artificial neural networks.
\end{abstract}

\section{Keywords}

Classification of polliniferous vegetation Multispectral imaging Neural networks 